\title{
Estudo do esqueleto em Trachemys dorbignyi (Duméril \& Bibron) (Reptilia, Testudines, Emydidae)
}

\author{
Ana Maria de Souza ${ }^{1}$ \\ Adriana Malvasio ${ }^{2}$ \\ Lívia Araújo Brito Lima ${ }^{2}$
}

\begin{abstract}
A Study about the Skeleton of Trachemys dorbignyi (Duméril \& Bibron, 1835) (Reptilia, Testudines, Emydidae). The skeleton of Trachemys dorbignyi (Duméril \& Bibron, 1835), based on 16 specimens incluind young and adult of both sexes is described. Designations of some structures are proposed and discussed based on data from literature and norms published in the THE WORLD ASSOCIATION OF VETERINARY ANATOMISTS (1994).

KEYS WORDS. Reptilia, Testudines, Trachemys dorbignyi, morphology, squeleton
\end{abstract}

PRITCHARD \& TREBBAU (1984) enfatizam o quanto a literatura herpetológica de modo geral é casual na América do Sul, sendo aquela referente a Testudines particularmente muito irregular.

A família Emydidae, a maior entre os quelônios viventes, tem distribuição da maioria de seus representantes no hemisfério Norte (PRITCHARD \& TREBBAU 1984). PRITCHARD (1979) menciona que a família Emydidae é composta por 85 espécies, poucas alcançando a América do Sul.

Segundo SeIDEL \& SMITH (1986), poucos arranjos de répteis americanos produziram mais confusão e controvérsia, especialmente nos últimos tempos, do que as tartarugas da família Emydidae do complexo Chrysemys Gray, 1844 Pseudemys Gray, 1855 - Trachemys Agassiz, 1857, onde está incluída a espécie Trachemys dorbignyi (Duméril \& Bibron, 1835).

Controvérsias taxonômicas ainda existem, inclusive quanto a considerar esta tartaruga como espécie ou subespécie. A opção do nome, Trachemys dorbignyi, foi por concordar com ERNST \& BARBOUR (1989).

Trachemys dorbignyi, conhecida popularmente como "tigre d'água", é uma tartaruga de água doce, preferindo segundo ERNST \& BARBOUR (1989), correntes fracas a moderadas, cuja distribuição abrange parte do Brasil, o Uruguai e o Norte da Argentina. No Brasil, ocorre especificamente no Rio Grande do Sul. No Maranhão, onde se pensava ser uma população introduzida, trata-se segundo VANZOLINI (1995), de uma outra espécie, por ele descrita, com base em seis exemplares, como Trachemys adiutrix Vanzolini, 1995. No Brasil, com exceção destas duas áreas, não se sabe ao certo se os outros relatos de ocorrência são de indivíduos introduzidos e também não há certeza da espécie a que pertencem (ERNST \& BARBOUR 1989).

1) Departamento de Zoologia, Instituto de Biociências, Universidade de São Paulo. Rua do Matão, Travessa 14, 101. 05508900 São Paulo, São Paulo, Brasil.

2) Campus Universitário de Araguaina, Fundação Universidade do Tocantins. Rua Humberto de Campos 508. 77807060 Araguaína, Tocantins, Brasil. 
GOMES (1994) salienta que no Brasil há falta de tradição na pesquisa de morfologia de répteis. Realmente, nessa área são escassos os trabalhos com quelônios brasileiros, sendo estes importantes para várias áreas de pesquisa, incluindo a Sistemática.

É importante mencionar alguns trabalhos anatômicos com Testudines, onde há descrição dos vários sistemas de órgãos, sendo estes de considerável ajuda para as dissecções. Podemos citar para a família Emydidae, o trabalho de BoJANus (1819-1821), Ashley (1955) e o de Noble \& Noble (1940), mas nenhum deles estudou especificamente $T$. dorbignyi.

As descrições osteológicas de um animal muitas vezes são importantes para diagnose da espécie. PRITCHARD \& TREBBAU (1984) comentam que podem ocorrer interessantes variações osteológicas em quelônios, entre espécies de um mesmo gênero, como por exemplo, a ausência ou a presença do vômer.

Mediante as informações acima apresentadas, este estudo propõe-se a descrever as diversas regiões do esqueleto de $T$. dorbignyi, e propor nomes às diversas estruturas estudadas utilizando as normas publicadas na Nômina Anatômica, Histológica e Embriológica Veterinária (1994).

\section{MATERIAL E MÉTODOS}

As tartarugas utilizadas neste trabalho foram fornecidas pela Fundação Parque Zoológico de São Paulo. Foram utilizados 16 exemplares, envolvendo machos e fêmeas, jovens e adultos. Nas figuras 1 e 2 encontram-se, respectivamente, um representante jovem e de um macho adulto e uma fêmea adulta.

Os desenhos realizados foram baseados, fundamentalmente em quatro espécimens, cujas medidas e idades encontram-se na tabela I; sendo que o restante dos exemplares foram utilizados para confirmar os caracteres observados.

Tabela I. Relação dos espécimes de Trachemys dorbigyni preparados pelo método de maceração, com as respectivas medidas, idade e sexo. (M) Machos, (F) fêmeas, (Ccar) comprimento da carapaça, (Lcar) largura da carapaça, (Cpla) comprimento do plastrão, (Lpla) largura do plastrão.

\begin{tabular}{llccccc}
\hline \multicolumn{1}{c}{ Exemplar } & Sexo & Idade (dias) & Ccar $(\mathrm{cm})$ & Lcar $(\mathrm{cm})$ & Cpla $(\mathrm{cm})$ & Lpla $(\mathrm{cm})$ \\
\hline UV07033* & Fêmea & 1218 & 11,8 & 10,3 & 10,4 & 7,6 \\
BP2303** & Fêmea & 1233 & 14,3 & 12,1 & 13,2 & 9,4 \\
CL21032* & Macho & 1242 & 12,5 & 10,8 & 10,9 & 8,0 \\
PD2303* & Fêmea & 2030 & 15,6 & 12,3 & 14,6 & 9,9 \\
JL04032 & Macho & 220 & 5,6 & - & 5,2 & 3,4 \\
AT08032 & Macho & 698 & 9,4 & 8,9 & 8,1 & 6,7 \\
AP0502 & Macho & 614 & 8,9 & - & 7,9 & 6,1 \\
AJ15023 & Macho & 72 & 3,6 & 3,3 & 3,5 & 2,6 \\
FY03012 & Macho & 280 & 5,3 & - & 5,1 & 3,3 \\
UV0103 & Fêmea & 1174 & 11,0 & 10,0 & 10,2 & 7,6 \\
C & Fèmea & 1642 & 15,7 & 13,3 & 14,8 & 10,1 \\
\hline
\end{tabular}

*) Os exemplares assinalados com asterisco fundamentaram as descrições e os esquemas anatômicos.

O modo como foram tomadas as medidas, com paquímetro de precisão $0,1 \mathrm{~mm}$, está descrito a seguir. Para a nomenclatura das estruturas que formam o casco (carapaça e plastrão), seguiu-se PRITCHARD \& TREBBAU (1984). 

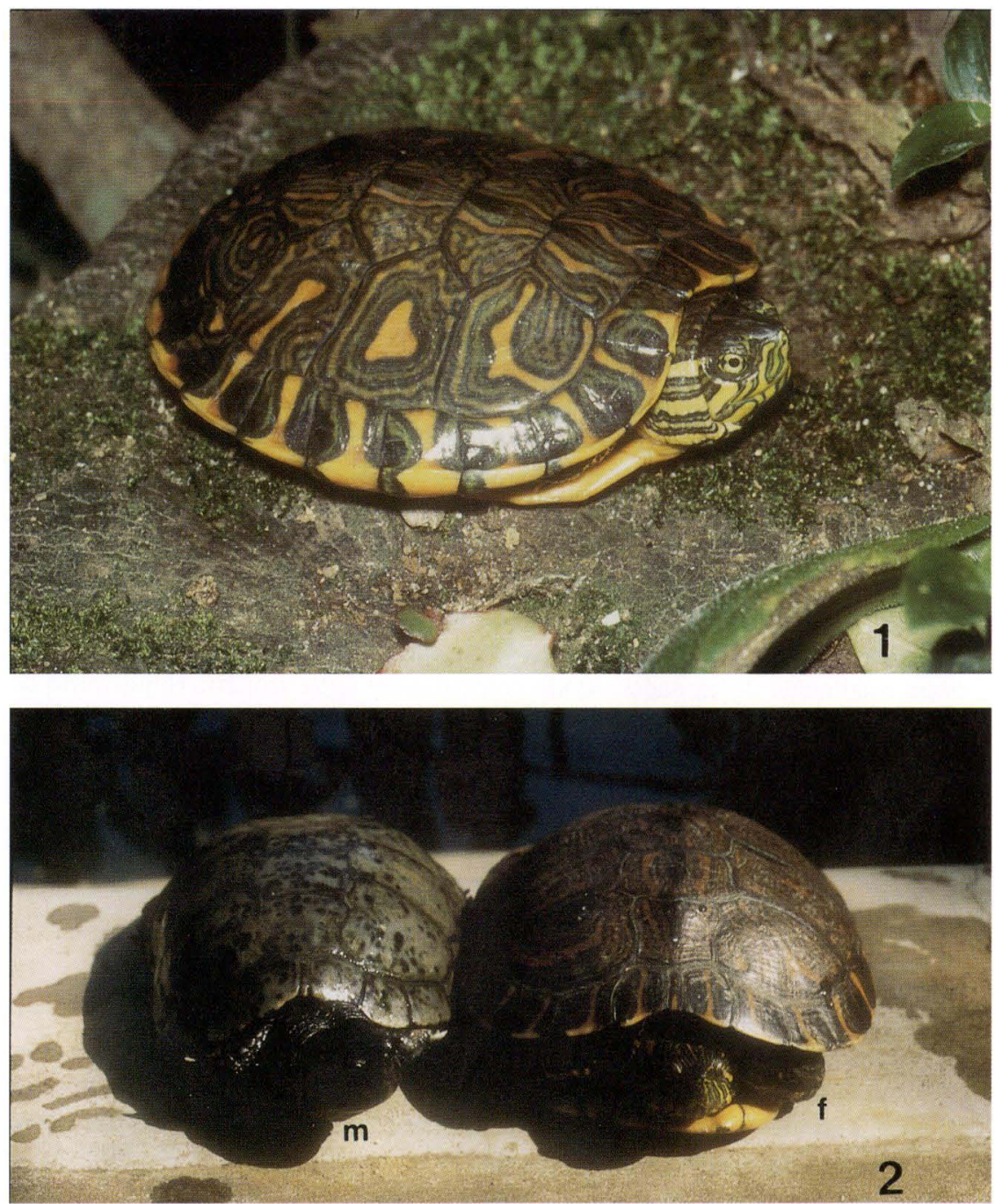

Figs 1-2. Trachemys dorbignyi. (1) Representante jovem; (2) representantes adultos. (m) Macho adulto, (f) fêmea adulta.

Comprimento da carapaça (Ccar) - é medido em linha reta, na parte medial (RHODIN \& MITTERMEIER 1976), que se estende desde a borda anterior do escudo nucal, até o final da sutura dos escudos supra caudais; largura máxima da carapaça (Lcar) - é a maior distância entre os escudos marginais de um lado a outro (CAGLE 1946); comprimento da sutura médio ventral do plastrão (Cpla) - a medida é feita a partir da junção dos escudos gulares, na parte mais anterior, indo até a junção dos escudos anais na parte mais posterior (MEDEM 1976); largura do plastrão (Lpla) - 
a medida é feita seguindo a sutura dos escudos peitorais e abdominais até o ponto onde esses dois escudos se encontram com os escudos marginais de ambos os lados (Flávio de Brros Molina, comunicação pessoal).

Após as tomadas de medidas, os animais foram sacrificados em câmara de éter sulfúrico, ou através de resfriamento.

Depois do sacrifício, iniciavam-se as dissecções, retirando-se primeiramente o plastrão com bisturi de lâmina fixa ou descartável, conforme o tamanho dos exemplares.

Retirando-se o plastrão, as vísceras foram totalmente removidas com o auxílio de pinças e tesoura de ponta fina e após este procedimento preparou-se o esqueleto por meio de dois métodos. $\mathrm{O}$ esqueleto dos exemplares jovens de maior porte e os adultos (11 espécimes) foi preparado através de fervura com posterior clareamento das peças, conforme GoMES (1989), e cinco jovens recém eclodidos foram submetidos a um processo de coloração e de diafanização baseado no modelo de TAYLOR \& VAN DYKE (1985).

Quanto ao método de GOMES et al. (1989) a fervura das peças se dá em água com amônia ou amoníaco a $1 \%$, até que a musculatura possa ser removida, o que ocorre mais facilmente com a peça ainda quente, utilizando-se tesouras e pinças finas, com o cuidado de não remover os ligamentos. O clareamento das peças ocorre após estas estarem totalmente descarnadas, sendo colocadas em água sanitária (hipoclorito de sódio) até atingirem um clareamento satisfatório. Logo após, as peças são lavadas e secas à sombra. O método de TAYLOR \& VAN DYKE (1985) empregado foi modificado quanto ao tempo de permanência dos exemplares nas soluções corantes.

Para a nomenclatura osteológica, utilizou-se BoJANUS (1819-1821), THOMSON (1932), Noble \& Noble (1940), ASHLEy (1955), RoMer (1956), WALKER (1973), STARCK (1979), e THE WORLD AsSOCIATION OF VETERINARY ANATOMISTS (1994).

\section{RESULTADOS}

\section{Carapaça e Plastrão}

A carapaça e o plastrão de $T$. dorbignyi são formados, respectivamente, por 50 e 9 placas ósseas e este revestimento ósseo é recoberto por escudos epidérmicos córneos. Os escudos córneos não correspondem exatamente às placas ósseas, sendo que as suturas entre eles deixam marcas sobre a carapaça e o plastrão observando-se as diferenças existentes entre as placas ósseas e os escudos córneos (Figs 3,4).

Os escudos córneos que revestem a carapaça de $T$. dorbignyi distribuem-se em três séries. A primeira série de escudos córneos é a mediana, também denominados escudos vertebrais (ev). É composta por cinco escudos hexagonais dispostos crânio-caudalmente entre o diminuto escudo nucal (en) e o escudo pigial ou supra-caudal (epi), sendo que estes dois últimos escudos pertencem à série de escudos marginais (em). A segunda série de escudos, denominada costal, é formada por oito grandes escudos córneos dispostos em duas fileiras, uma direita e outra esquerda, cada uma delas com quatro placas (eco). A terceira e última série de escudos córneos é a marginal composta por 25 escudos que revestem a margem externa da carapaça. O escudo nucal, é proporcionalmente o menor de todos e reveste a placa óssea nucal da carapaça (Fig. 3). 

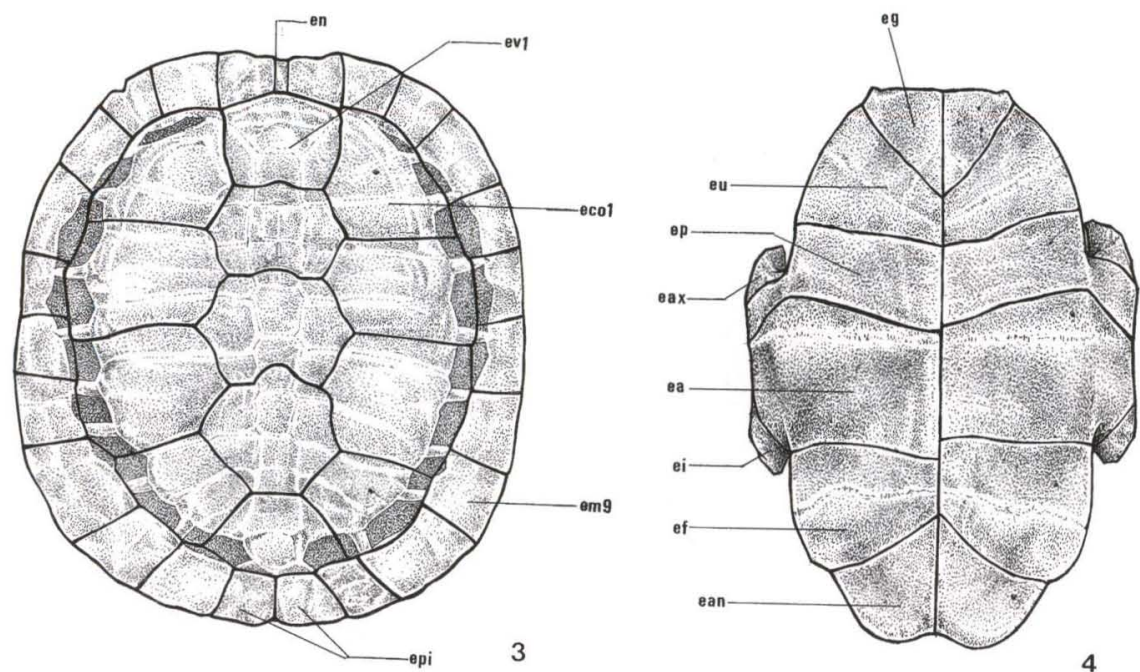

Figs 3-4. Trachemys dorbignyi, esquema dos escudos córneos. (3) Vista dorsal da carapaça; (4) vista ventral do plastrão. (eco1) Primeiro escudo costal, (em9) nono escudo marginal, (en) escudo nucal, (epi) escudo pigial, (ev1) primeiro escudo vertebral, (ea) escudo abdominal, (ean) escudo anal, (eax) escudo axilar, (ef) escudo femural, (eg) escudo gular, (ei) escudo inguinal, (ep) escudo peitoral, (eu) escudo umeral.

O plastrão é recoberto externamente por dezesseis escudos córneos pareados e denominados segundo uma disposição crânio-caudal de: escudos gulares (eg); escudos umerais (eu); escudos peitorais (ep); escudos abdominais (ea); escudos femorais (ef) e escudos anais (ean). Situados látero-cranialmente aos escudos peitorais, encontram-se dois pequenos escudos axilares (eax) e látero-caudalmente aos escudos abdominais, definem-se dois escudos os inguinais (ei) (Fig. 2B).

A carapaça óssea de $T$. dorbignyi é formada por três séries de placas ósseas. Uma série mediana composta por 11 placas ósseas, sendo sete placas vertebrais (pv), 1 nucal (pn), 2 supra-pigiais (pspi 1 e pspi 2) e 1 pigial (ppi); lateralmente à série mediana encontram-se 16 placas ósseas associadas às costelas, são as placas costais (pco), dispostas em 8 pares; e, uma série de 22 placas ósseas marginais (pm) que circundam as placas das série mediana e costal e delimitam a margem externa da carapaça óssea (Figs 5,6). A placa marginal mais cranial, é a nucal e as três placas mais caudais são as supra-pigiais 1 e 2 , e a pigial, sendo que esta última apresenta uma conspícua depressão medial (dm) (Figs 5, 6).

As placas da série costal como as da série marginal apresentam diferentes graus de ossificação com áreas cartilaginosas (ac) e, aparentemente, as craniais ossificam-se antes das caudais ao longo da vida dos animais, segundo as observações feitas nos exemplares jovens e adultos estudados (Figs 5, 6).

O plastrão ósseo é formado por oito placas pareadas e uma ímpar. As placas ósseas pareadas dispostas crânio-caudalmente são denominadas: epiplastrão (epp), 

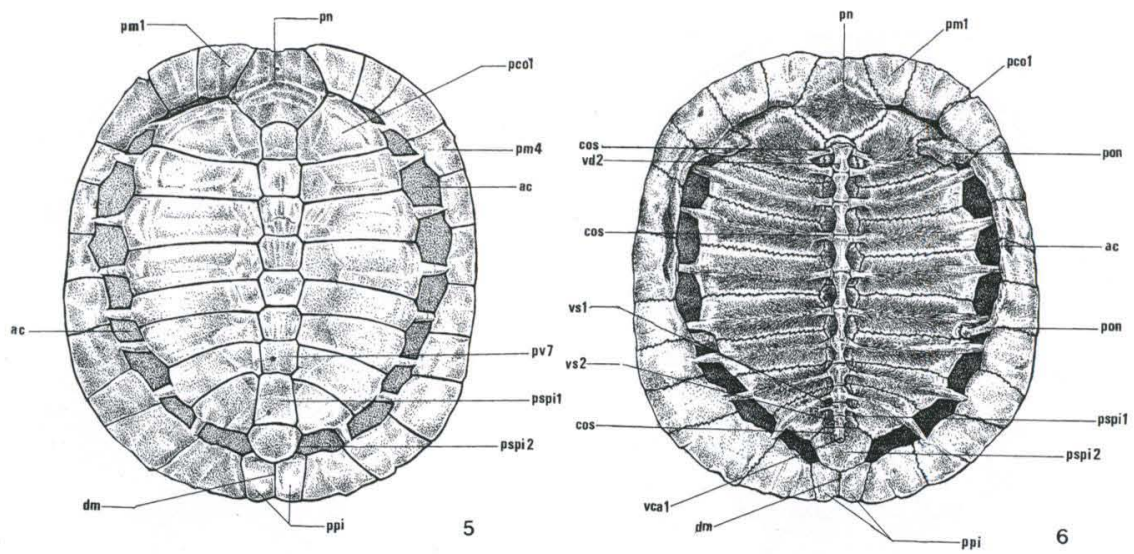

Figs 5-6. Trachemys dorbignyi, esquema das placas ósseas. (5) Vista dorsal da carapaça; (6) vista ventral da carapaça. (ac) Áreas cartilaginosas, (cos) costelas, (dm) depressão medial, (pco1) primeira placa costal, $(\mathrm{pm} 1)$ primeira placa marginal, $(\mathrm{pm} 4)$ quarta placa marginal, $(\mathrm{pn})$ placa nucal, (pon) ponte, (ppi) placa pigial, (pspi1) primeira placa supra pigial, (pspi2) segunda placa supra pigial, (pv7) sétima placa vertabral, (vca1) primeira vértebra caudal, (vd2) segunda vértebra dorsal, (vs1) primeira vértebra sacral, (vs2) segunda vértebra sacral.

hioplastrão (hi), hipoplastrão (hp), e xifoplastrão (xp). Caudal às duas placas do epiplastrão e cranial às do hioplastrão encontra-se uma placa ímpar, o entoplastrão (ent) (Figs 7,8).

As placas do hio- e hipoplastrão formam as pontes ósseas (pon) que conectam o plastrão à carapaça. Nas faces cranial e caudal das pontes delineiam-se quatro placas de reforço, duas craniais (prc) e duas caudais (prca) (Fig. 8).

\section{Crânio}

Os ossos crânianos da série mediana dorsal, dispostos caudo-rostralmente são: o supra-occipital (so), os parietais (pa), os frontais (f), os pré-frontais (pf) e os pré-maxilares (pma) (Fig. 9). Observa-se uma crista occipital (co) conspícua cuja margem ventral limita-se com o supra-occipital e a rostral continua-se pela margem caudal dos parietais. A face externa lateral do supra-occipital e dos parietais delimitam a face dorso-lateral de uma conspícua depressão posterior do crânio (dp) (Figs 9, 10).

A depressão posterior do crânio é limitada látero-ventro-caudalmente pelo opistótico (op), e látero-ventro-rostralmente pelo pré-ótico (pro) (Fig. 9). O opistótico, o pré-ótico e o esquamosal (e), formam a maior parte do assoalho da depressão e a parede lateral externa desta é delimitada por uma crista rostro-caudal do esquamosal (ce) (Figs 9, 10).

O esquamosal expressivamente expandido, delimita a face látero-caudal do crânio onde definem-se as margens: esquamosal-opisto-pré-ótica, esquamosal-pósorbital, esquamosal-quadradojugal e esquamosal-quadrada (Fig. 10). A margem 

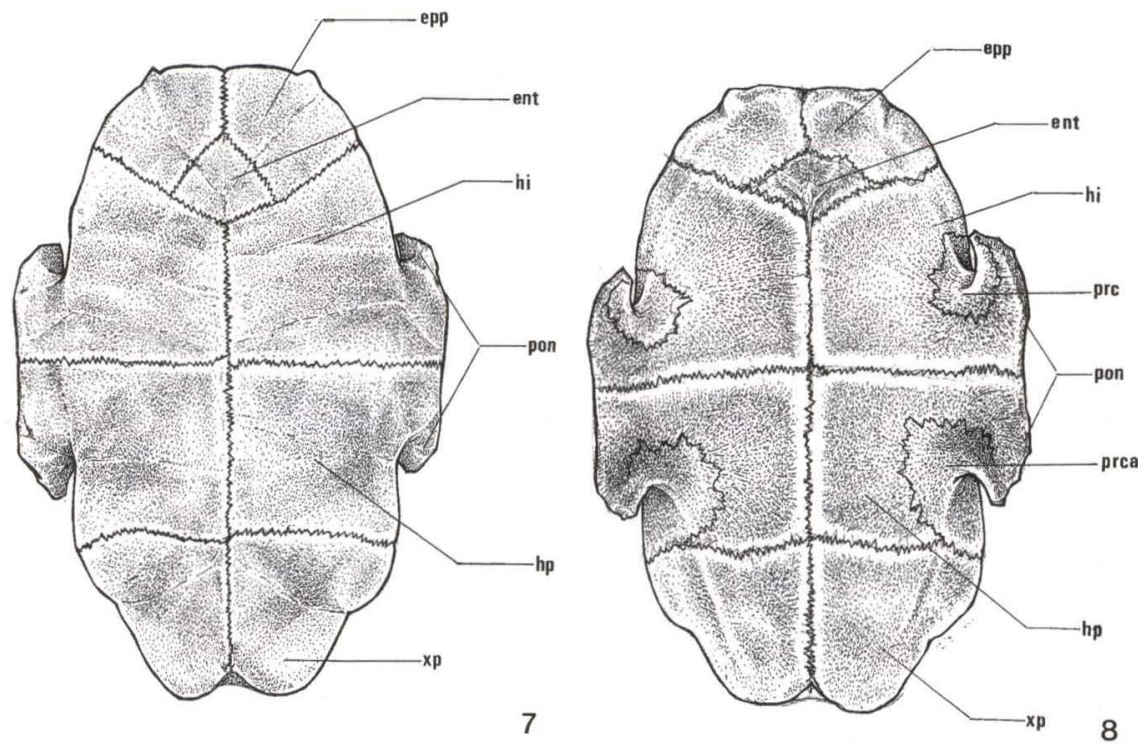

Figs 7-8. Trachemys dorbignyi, esquema das placas ósseas. (7) Vista ventral (externa) do plastrão; (8) vista dorsal (interna) do plastrão. (ent) Entoplastrão, (epp) epiplastrão, (hi) hioplastrão, (hp) hipoplastrão, (pon) ponte óssea, (prca) placa de reforço caudal, (prc) placa de reforço cranialxp- xifoplastrão.
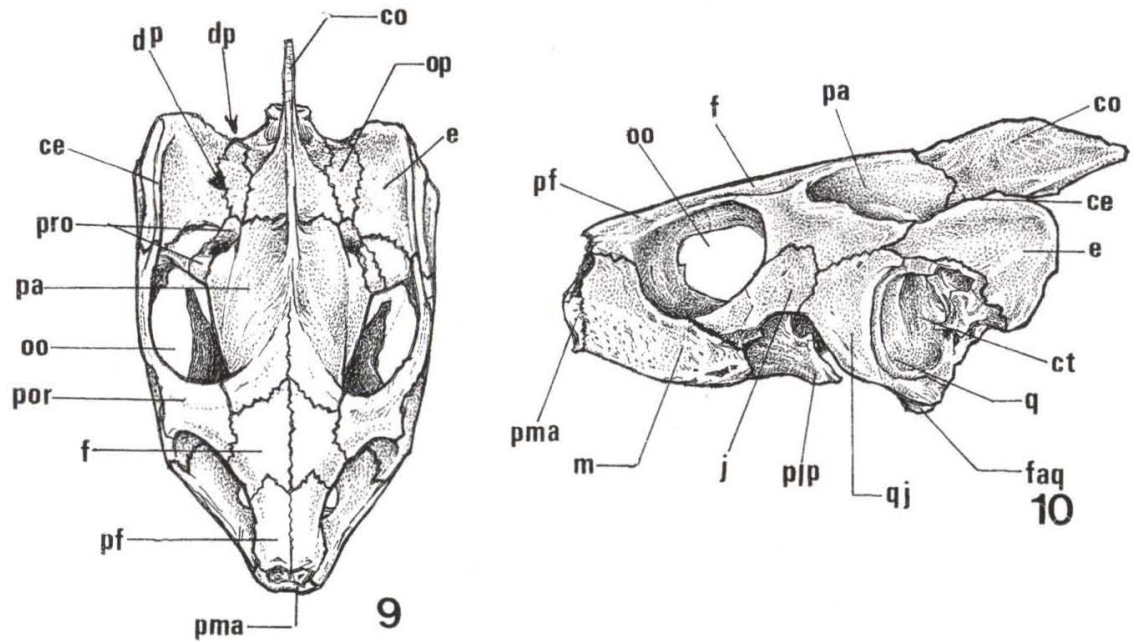

Figs 9-10. Trachemys dorbignyi, esquema do crânio. (9) Vista dorsal; (10) vista lateral. (ce) Crista do esquamosal, (co) crista occipital, (ct) cavidade timpânica, (dp) depressão posterior, (e) esquamosal, (f) frontal, (faq) face articular do quadrado, (j) jugal, (m) maxilar, (op) opistótico, (oo) órbita ocular, (pa) parietal, (por) (pós) orbital, (pf) pré-frontal, (pma) pré-maxilar, (pro) pré-ótico, (plp) processo látero posterior do pterigóide, (q) quadrado, (qj) quadrado jugal. 
esquamosal-quadrado alcança a área da articulação mandíbula crânio, que está alojada na face ventral do quadrado (q). A área da articulação do quadrado delimita a face articular do quadrado (faq) (Figs 10-12).
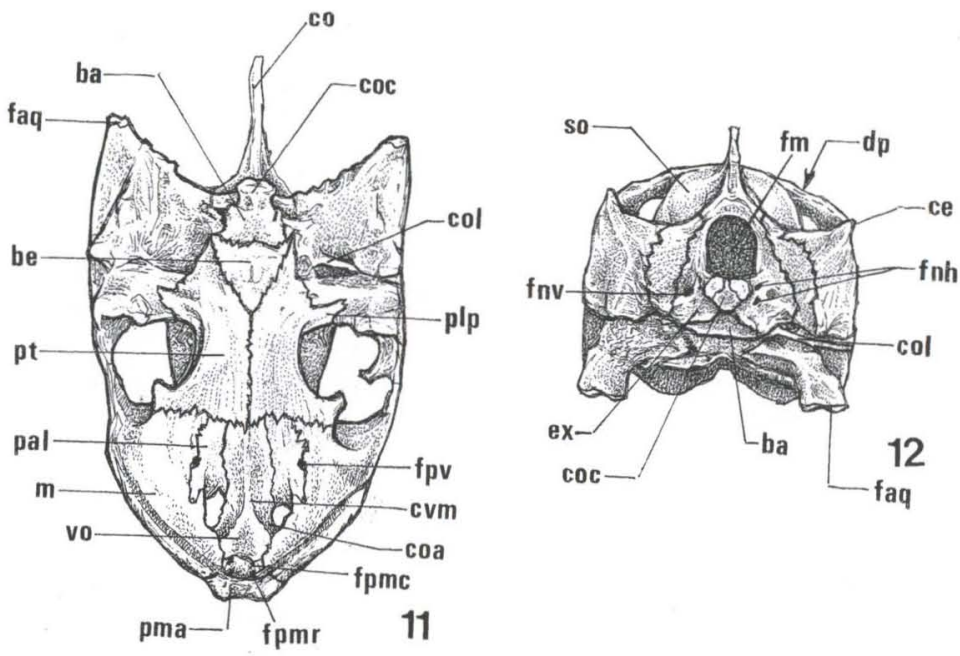

Figs 11-12. Trachemys dorbignyi, esquema do crânio (11) Vista ventral; (12) vista occipital. (ba) Basioccipital, (be) basioesfenóide, (ce) crista do esquamosal, (coa) coana, (col) columela, (coc) côndilo occipital, (co) crista occipital, (cvm) crista vomeriana medial, (dp) depressão posterior, (ex) exoccipital, (faq) face articular do quadrado, (fm) forame magno, (fnh) forame do nervo hipoglosso, (fnv) forame do nervo vago, (fpv) forame palatino-vomeriano, (fpmc) forame (pré) maxilar caudal, (fpmr) forame (pré) maxilar rostral, (m) maxilar, (pal) palatino, (pma) pré-maxilar, (plp) processo látero-posterior do pterigóide, (pt) pterigóide, (so) supra-occipital, (vo) vômer.

A região occipital é formada, respectivamente, ventro-, látero-dorsalmente, por um diminuto basioccipital (ba), dois exoccipitais (ex) expandidos lateralmente, e um supra-occipital (so) onde diferencia-se a crista occipital. Este ossos margeiam o forame magno (fm), e as porções, ventral do basioccipital, e caudal dos exoccipitais, formam o côndilo occipital (coc) (Figs 11, 12).

O côndilo occipital tricuspidado apresenta duas depressões pouco nítidas, as incisuras jugulares (ij) e na porção caudal de cada uma de suas faces laterais externas delineia-se um diminuto processo occipital (poc) (Fig. 11).

Na porção ventro-lateral-caudal de cada um dos exoccipitais situam-se dois forames. O mais interno, denominado forame do nervo vago (fnv) situa-se próximo à margem exoccipital-opistótica, e o mais externo, caudal ao anterior, é duplo o forame do hiplogloso (fnh) que dá passagem não só ao IX nervo craniano como também a nervos acessórios espinhais (Fig. 12).

Observa-se em vista lateral do crânio a depressão posterior, a cavidade timpânica (ct) e a órbita ocular (oo) (Fig. 10). A face externa lateral do crânio, a arcada, é formada pelo maxilar (m), jugal (j), quadrado-jugal (qj), quadrado (q) e pós-orbital (por) (Fig. 10). 
A órbita ocular é circundada rostralmente pelo pré-frontal e maxilar, dorsalmente pela margem orbital do frontal, dorso-caudalmente pelo pós-orbital e caudalmente pelo jugal. Os maxilares limitam-se rostralmente com os pré-maxilares formando a margem externa da maxila superior. Os maxilares formam a maior parte desta margem e junto com os diminutos pré-maxilares sustentam o bico córneo superior (bcs) (Fig. 13).

A cavidade timpânica é circundada rostralmente pelo quadrado-jugal, dorsalmente pelo esquamosal e mediana-, ventralmente pelo quadrado (Fig. 10). Observa-se a columela ( $\mathrm{col})$ no interior do meato acústico externo, atravessando o poro acústico externo e estendendo-se até a janela oval (Fig. 12). O opistótico forma as porções caudal, dorsal e mediana do labirinto ósseo e o pró-ótico contribui com parte da porção mediana e da dorsal rostral desta estrutura.

Os ossos cranianos pertencentes a série mediana ventral, dispostos caudorostralmente, são: o basioccipital (ba), o basioesfenóide (be), pterigóides (pt), palatinos (pal), vômer (vo) e pré-maxilares (pma). O basioccipital contribui com a porção ventral do côndilo occipital e limita-se rostralmente com o basioesfenóide comparativamente maior. Este último limita-se rostralmente com a margem caudal do pterigóide (Fig. 11).

Os pterigóides são os maiores ossos da série ventral encontram-se separados entre si em sua porção mediana-caudal pelo basioesfenóide e ao longo de seu comprimento unem-se medialmente (Fig. 11). Limita-se rostro-medialmente com o vômer, os palatinos e os maxilares, e caudo-lateralmente o pterigóide apresenta uma conspícua projeção, ou processo látero-posterior (plp), onde definem-se as margem pterigóidea-quadrada, pterigóidea-exoccipital e pterigóidea-parietal (Fig. 11).

A margem medial dos ossos palatinos limita-se com o vômer e na porção média de cada uma das margens palatina-vomerianas encontra-se o forame palatino-vomeriano (fpv) (Fig. 11). O vômer apresenta uma crista medial, crista vomeriana medial (cvm), que separa medialmente as coanas internas (coa). Este osso ímpar limita-se rostralmente com os pré-maxilares e, próximos à margem pré-maxilar-vomeriana, delimitam-se dois pares de diminutos forames, o forame pré-maxilar rostral e o caudal (fpmr, e fpmc) (Fig. 11).

A mandíbula é formada por seis pares de ossos dispostos caudo-rostralmente: articular (ar), dentário (d), esplenial (es), angular (an), supra-angular (san) e coronóide (cor) (Figs 14, 15). O articular tem posição caudal na mandíbula, limita-se ventro-lateralmente com o angular e lateralmente com o supra-angular. A sua face dorsal corresponde a área de articulação com o quadrado onde delimita-se uma fossa glenóide (fgl) e na porção ventro-caudal do articular define-se o processo retro-articular (pra) (Figs 14, 15). A margem rostral do articular limita a parede caudal da fossa adutora (fa). A fossa adutora estende-se rostralmente e é limitada lateralmente por duas cristas dorsais do supra-angular, uma interna ou medial (csam) e outra externa (csae) (Fig. 14).

O dentário é o osso de maior tamanho dentre todos os elementos mandibulares e ocupa a maior extensão da superfície externa da mandíbula representando a maior área de sustentação do bico córneo mandibular. A face interna do dentário limita-se ventro-lateralmente com o esplenial, ventro-caudalmente com o angular, latero-caudalmente com o supra-angular e dorso-caudalmente com o coronóide (Fig. 14). 

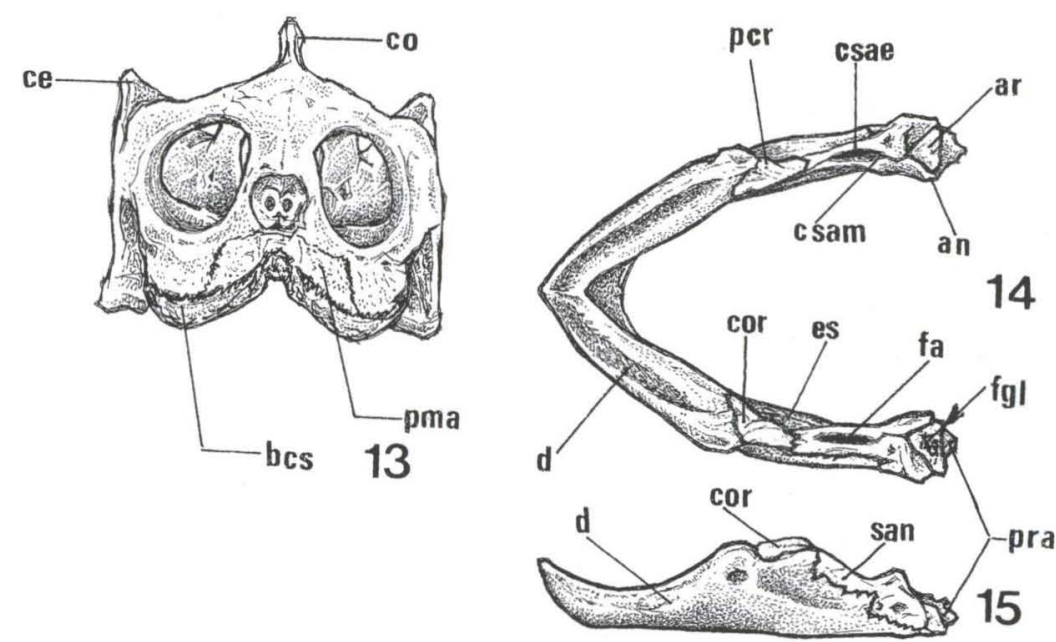

Figs 13-15. Trachemys dorbignyi. (13) Esquema do crânio em vista frontal; (14) esquema da mandíbula em vista dorsal; (15) esquema da mandibula em vista lateral. (an) Angular, (ar) articular, (bcs) bico córneo superior, (cor) coronóide, (ce) crista do esquamosal, (co) crista occipital, (csae) crista supra-angular externa, (csam) crista supra-angular medial, (d) dentário, (es) esplenial, (fa) fossa adutora, (fgl) fossa glenóide, (pcr) processo coronóide, (pma) pré-maxilar, (pra) processo retro-articular, (san) supra-angular.

O esplenial ocupa uma pequena porção da face externa ventral da mandíbula, mas internamente contribui com o assoalho e paredes internas do canal meckeliano (ou de Meckel). Limita-se caudalmente com o angular e dorso-rostralmente com o dentário.

O osso coronóide é proporcionalmente o menor dos elementos mandibulares. Encontra-se na face superior da mandíbula, caudal ao dentário, suas faces laterais e ventral limitam-se com o supra-angular, e constitui a margem rostral da fossa adutora. A sua maior área corresponde ao processo coronóide (pcr) que fornece sustentação à porção caudal do bico córneo mandibular (Fig. 14).

\section{Aparelho Hióideo}

As diferentes estruturas que formam o aparelho hióideo de $T$. dorbignyi apresentam graus variáveis de ossificação. O corpo do hióide (ch) é a peça ventral central cuja face interna, ou dorsal, é levemente côncava onde se aloja a parte cranial da laringe (Fig. 16). Em sua margem cranial o corpo do hióide apresenta o processo lingual ( $\mathrm{pl}$ ) pouco desenvolvido que se limita com o processo entoglossal (pen), e no terço cranial do corpo do hióide situa-se a janela medial (jm).

O processo entoglossal é bem visível nas peças submetidas ao processo de coloração e diafanização e sua forma aproxima-se a de uma seta (Fig. 16) onde definem-se quatro margens duas craniais e duas caudais.

O corpo do hióide é uma peça robusta ocupando quase todo o assoalho bucal. Em cada uma de suas margens laterais situam-se três áreas de articulação localizadas individualmente em um processo lateral do hióide (plh). Cada uma destas articulações está associada a um corno hióideo (Fig. 16). 

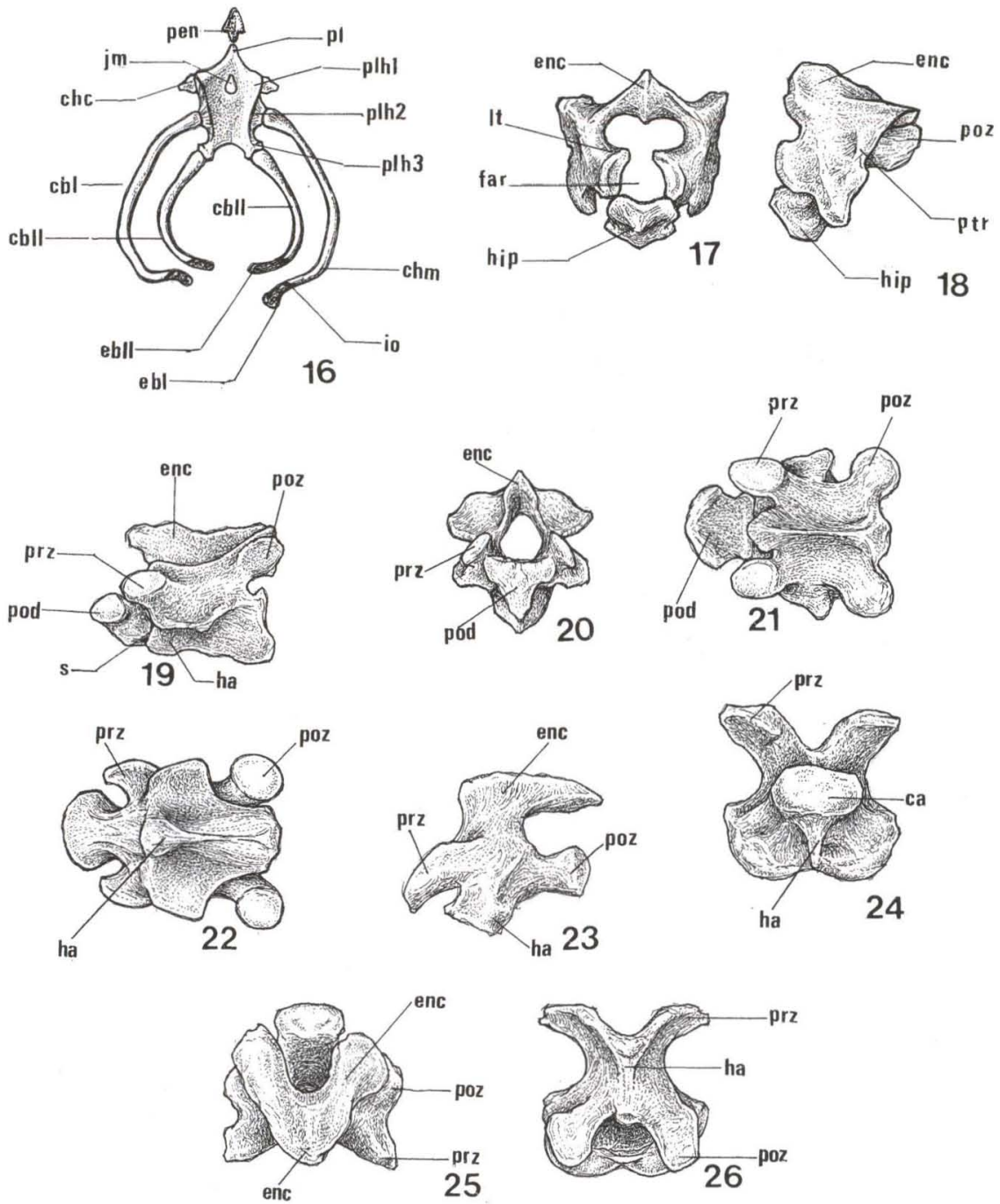

Figs 16-26. Trachemys dorbignyi. (16) Esquema da vista dorsal do aparelho hióideo; (17) esquema do atlas em vista frontal; (18) esquema do atlas em vista lateral; (19) esquema do axis em vista lateral; (20-22) esquema do axis em vista (20) frontal, (21) dorsal, (22) ventral; (23-26) esquema da oitava vértebra em vista (23) lateral, (24) frontal, (25) dorsal, (26) ventral. (ca) Cabeça da vértebra, (cbl) primeiro ceratobranquial, (cbll) segundo ceratobranquial, (chc) corno hióideo cranial, (chm) corno hióideo médio, (ebl) primeiro epibranquial, (ebll) segundo epibranquial, (io) inserção obliqua, (enc) espinho neural cervical, (far) forame alar, (ha) hipoapófise, (hip) hipocentro, (jm) janela medial, (It) ligamento transverso, (pen) processo entoglossal, ( $\mathrm{pl}$ ) processo lingual, (plh1) primeiro processo lateral do hióide, (plh2) segundo processo lateral do hióide, (plh3) terceiro processo lateral do hióide, (pod) processo odontóide, (poz) pós-zigapófises, (prz) pré-zigapófises, (ptr) processo transverso, (s) sutura. 
Os cornos hióideos são estruturas pareadas; o cranial, o médio e o caudal. Os corpos hióideos craniais (chc) são duas diminutas peças cônicas. O par de cornos hióideos médios (chm) é formado por uma peça proximal, o primeiro ceratobranquial (cbI), e uma peça distal, o primeiro epibranquial (ebI) (Fig. 16). Na porção proximal do cbI, denominada cabeça do ceratohial, localiza-se a área de articulação com o processo lateral. $\mathrm{O}$ ebI é um elemento filamentoso e cartilaginoso que se fixa à extremidade distal do cbI por meio de uma inserção oblíqua (io) (Fig. 16). Os cornos hióideos caudais (chca) são menores que os cornos hióideos médios e são formados por uma peça proximal, o segundo ceratobranquial (cbII), e outra distal, o segundo epibranquial (ebII), que é totalmente cartilaginosa e também une-se ao ceratobranquial II por meio de uma inserção oblíqua (Fig. 16).

\section{Coluna Vertebral}

A coluna vertebral apresenta 8 vértebras cervicais ( $\mathrm{vc}$ ), 10 dorsais ( $\mathrm{vd}), 2$ sacrais (vs) e de 25 a 30 vértebras caudais (vca) (Fig. 6). As vértebras cervicais e caudais estão livres da carapaça diferentemente das dorsais e das sacrais que estão fundidas à ela. As primeiras cinco vértebras cervicais alinham-se em linha reta enquanto as três vértebras subseqüentes alinham-se obliquamente ao eixo crânio-caudal do corpo.

O corpo vertebral das vértebras cervicais é maior que o dos outros tipos vertebrais. Os corpos vertebrais cervicais têm maior comprimento que os arcos neurais correspondentes delimitando, deste modo, grandes espaços entre os arcos neurais. A região basal destes arcos neurais é cartilaginosa. Estas áreas cartilaginosas estão presentes em todos os exemplares incluindo as formas adultas. As pré-zigapófises (prz) ou processo articular cranial (pac) situam-se cranialmente ao arco neural e posteriormente situam-se as pós-zigapófises (poz) (Figs 19, 21, 22).

Os espinhos neurais cervicais (enc), são cartilaginosos em sua porção basal. O espinho neural da $1^{\mathrm{a}}$ e $2^{\mathrm{a}}$ vértebras são pouco desenvolvidos (Figs 17-22), o da $3^{\mathrm{a}}, 4^{\mathrm{a}}, 5^{\mathrm{a}}$ e $6^{\mathrm{a}}$ vértebras ausentes, e $o$ da $7^{\mathrm{a}}$ e $8^{\mathrm{a}}$ vértebras tem a forma de um $\mathrm{V}$ (Figs 23,25 ). $\mathrm{O}$ vértice deste $\mathrm{V}$ está direcionado para a cabeça da vértebra (ca) e, cada uma das extremidades alcança a fase dorsal das pós-zigapófises direita e esquerda (Figs 24, 25).

$\mathrm{Na}$ face ventral mediana do corpo vertebral define-se uma hipoapófise, ou processo espinhoso ventral (hi). A hipoapófise é laminar e em sua porção basal é cartilaginosa. Esta estrutura diminui de tamanho ao longo da série de vértebras cervicais, isto é, são mais desenvolvidas na $2^{\mathrm{a}}$ e $3^{\mathrm{a}}$ vértebras (Figs 19, 22), proporcionalmente menores na $4^{\mathrm{a}}$ e $5^{\mathrm{a}}$ vértebras e extremamente reduzidas na $6^{\mathrm{a}}$ e $7^{\mathrm{a}}$ vértebras. No entanto, a hipoapófise da $8^{\mathrm{a}}$ vértebra é uma projeção conspícua localizada próxima à margem ventral da cabeça da vértebra (Figs 23, 24).

A primeira vértebra cervical, o atlas, tem forma de um anel. O corpo vertebral, denominado hipocentro (hip), delimita ventralmente o forame alar (far) (Fig. 17), uma cavidade que aloja o processo odontóide (pod) da $2^{\mathrm{a}}$ vértebra (Fig. 19). O forame alar é limitado látero-dorsalmente pelo ligamento transverso (lt) (Fig. 17). $\mathrm{O}$ atlas caracteriza-se também por apresentar pós-zigapófises bem alargadas e apresentar um par de processos transversos (ptr) diminutos, localizados em cada uma das faces látero-ventrais do corpo vertebral (Fig. 18). 
A segunda vértebra, o axis, caracteriza-se pela presença de um processo odontóide muito desenvolvido, cuja face cranial levemente côncava articula-se com o côndilo occipital (Figs 19-21). A face caudal do processo odontóide limita-se, por meio de uma sutura (s), com o restante do corpo vertebral. As pré-zigapófises localizam-se na mesma linha do arco neural e as pós-zigapófises situam-se mais caudalmente ao corpo vertebral, de modo semelhante ao que ocorre com o restante das vértebras cervicais (Figs 19, 21, 22).

As vértebras dorsais (vd) caracterizam-se por estarem fundidas àcarapaça por meio do arco neural. A primeira vértebra dorsal (nona vértebra corpórea) diferencia-se das demais dorsais por possuir: pré-zigapófises; centro vertebral proporcionalmente mais curto e mais largo que as demais vértebras dorsais; e cabeça vertebral acentuadamente côncava. Associam-se a cada duas vértebras dorsais um par de costelas (Fig. 6). A extremidade proximal das costelas apresenta um par de tubérculos (tubérculos costais), um cranial e outro caudal. Cada um dos tubérculos apresenta uma área de articulação, a cranial contacta-se com a fóvea costal caudal, da vértebra mais cranial, e a caudal contata-se com a fóvea costal cranial, da vértebra subseqüentemente posterior. A porção proximal das costelas dorsais define junto com o centro vertebral correspondente, um espaço abaixo da caparaça óssea (Fig. 6). O espaço contido entre a primeira e segunda costelas é comparativamente maior e aloja a face costal da escapula.

O corpo vertebral da $10^{\mathrm{a}}$ a $18^{\mathrm{a}}$ vértebras dorsais são mais longos que largos, enquanto o da $19^{\mathrm{a}}$ e $20^{\mathrm{a}}$ vértebras tem comprimento e largura semelhantes (Fig. 6). A $19^{\mathrm{a}}$ e $20^{\mathrm{a}}$ vértebras são as sacrais e estão associadas à placa supra-pigial 1 da carapaça óssea (Fig. 6). Cada um dos corpos vertebrais destas duas vértebras encontra-se associado a um par de diminutas costelas (Fig. 6). A articulação costela $\mathrm{x}$ corpo vertebral é feita por meio dos dois tubérculos costais e as respectivas fóvea vertebral costal e ventral. O corpo da costela é retilíneo, achatado dorso-ventralmente e limita-se distalmente com o tubérculo ventral. O tubérculo ventral é expandido, achatado dorso-ventralmente definindo uma área de articulação ampla associada a articulação da região cranial do ílio (Figs 30, 32).

As vértebras caudais (vca) são móveis, isto é, não estão fundidas à carapaça dorsal. $\mathrm{O}$ arco neural das vértebras caudais é diminuto e totalmente cartilaginoso. Proporcionalmente, são as menores vértebras do corpo diminuindo de tamanho ao longo do eixo crânio-caudal. O centro vertebral destas vértebras é tão largo quanto longo assumindo forma, aproximadamente, quadrada. O centro vertebral das primeiras seis vértebras caudais encontra-se associado a um par de diminutas costelas (cos) fundidas ao corpo vertebral (Fig. 6).

\section{Cintura Escapular}

A cintura escapular (peitoral) de T. dorbignyi formada por três peças ósseas [escápula (esc), processo acromial (pac) e coracóide (cr)] dispostas sobre três eixos que irradiam de um ponto central (Fig. 27). A escápula de forma colunar estende-se dorso-lateralmente em direção à carapaça óssea. A face costal da escápula (fce) é expandida definindo uma margem que é a área de articulação com a primeira costela (Fig. 27). Na face lateral da escápula (fle) definem-se duas estruturas, uma área de 

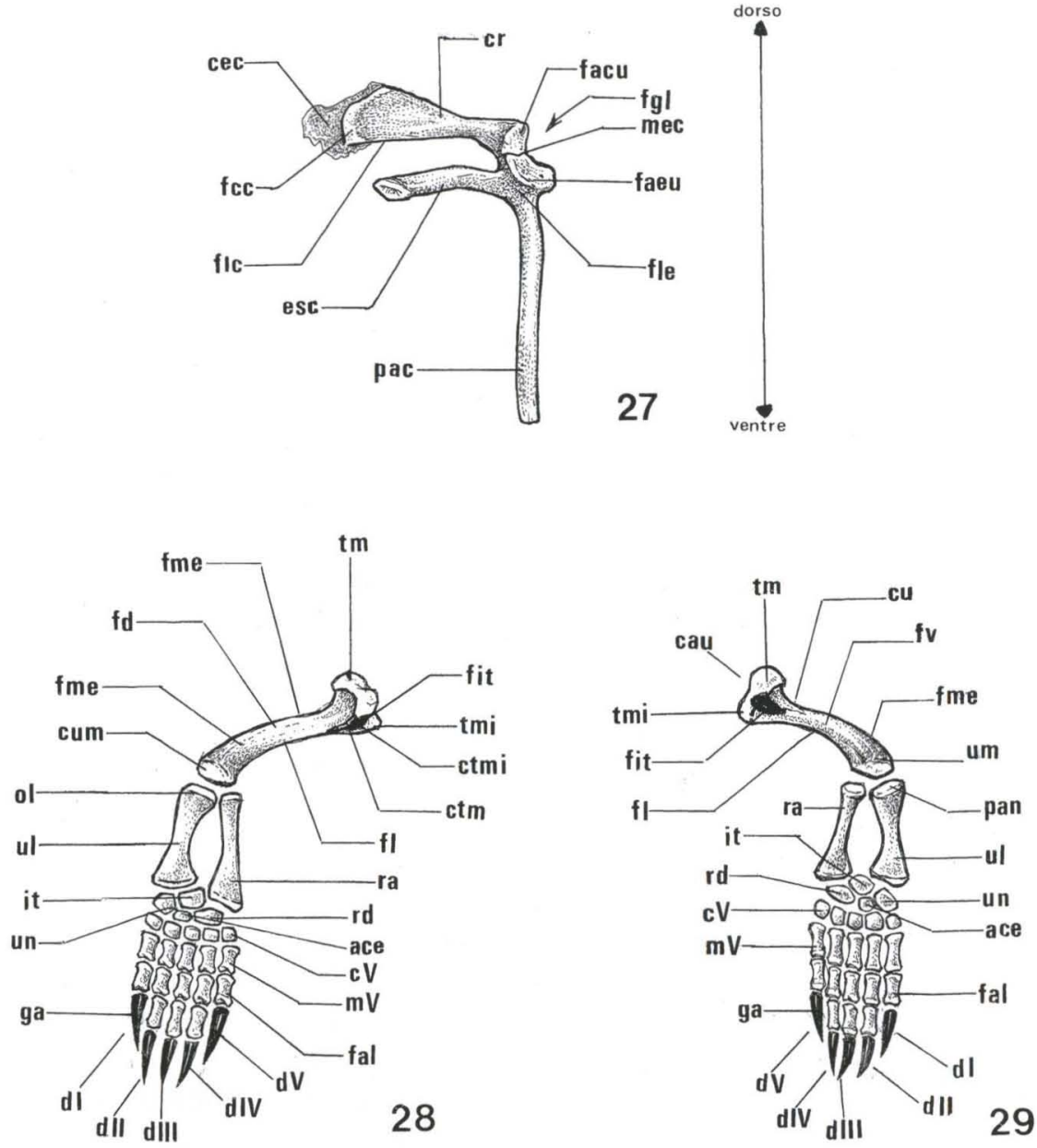

Figs 27-29. Trachemys dorbignyi. (27) Esquema da cintura peitoral direita em vista lateral; (28-29) esquema do membro anterior direito em vista (28) látero-dorsal, (29) vista látero-ventral. (ace) acessório, (cau) cabeça do úmero, (cec) cartilagem epicoracóide, (cu) colo do úmero, (cum) côndilo umeral, (cr) coracóide, (ctm) crista tubérculo maior, (ctmi) crista tubérculo menor, (cV) quinto carpal, (dl) primeiro dígito, (dll) segundo dígito, (dIII) terceiro dígito, (dIV) quarto digito, (dV) quinto dígito, (esc) escápula, (facu) face de articulação coracóidea-umeral, (faeu) face de articulação escapular-umeral, (fal) falanges, (fcc) face costal do coracóide, (fd) face dorsal, (fit) fossa inter-tubercular, (fl) face lateral, (fle) face lateral da escápula, (flc) face lateral do coracóide, (fgl) fossa glenóide, (fme) face medial, (fal) falanges, (fit) fossa inter-tubercular, (fv) face ventral, (ga) garra, (it) intermédio, (mec) margem escapular-coracóidea, (mV) quinto metacarpal, (ol) olecrano, (pac) processo acromial, (pan) processo ancôneo, (rd) radial, (ra) rádio, (tm) tubérculo maior, (tmi) tubérculo menor, (ul) ulna, (um) úmero, (un) ulnar. 
articulação e um conspícuo processo acromial. Nesta área de articulação define-se a margem que a limita com o osso coracóide, margem escápular-coracóidea (mec), e a face de articulação com o úmero (u), face de articulação escápular-umeral (faeu) (Fig. 27).

O processo acromial forma com a escápula um ângulo próximo a $90^{\circ}$ (Fig. 27). É uma estrutura também colunar estendendo-se dorso-ventralmente em direção ao plastrão ósseo, e sua extremidade ventral apresenta uma área cartilaginosa (Fig. 27).

O osso coracóide tem o mesmo comprimento que a escápula, mas é mais largo do que esta (Fig. 27). Estende-se caudo-medialmente a partir da área de articulação com a escápula e sua face costal (face costal do coracóide- fcc) é muito expandida e continua-se por uma área cartilaginosa, a cartilagem epicoracóide (cec) (Fig. 27). A face lateral do coracóide (flc) diferencia-se em uma articulação com o úmero, face articular coracóidea-umeral (facu) (Fig. 27).

A face de articulação da escápula e do coracóide com o úmero definem uma fossa glenóide (fgl) onde se aloja a cabeça do úmero (Fig. 27).

\section{Membros Anteriores}

O corpo do úmero é cilíndrico e encurvado ao longo de seu maior eixo, definindo-se uma face medial convexa (fme) e uma face lateral côncava (fl), e na extremidade proximal apresenta leve estreitamento que corresponde ao colo do úmero (cu). Na face cranial do colo do úmero diferencia-se a cabeça do úmero (cau) onde se diferencia a área de articulação com a fossa glenóide da cintura pélvica (Figs $28,29)$. A cabeça do úmero apresenta também dois tubérculos, um maior (tm) outro menor (tmi), que delimitam em sua face ventral duas cristas, a crista do tubérculo maior e a crista do tubérculo menor - (ctm e ctmi). Estas duas cristas limitam a fossa inter-tubercular (fit) (Figs 28, 29).

A extremidade distal do úmero é expandida, denominada côndilo umeral (cum), onde situam-se as áreas de articulação do úmero com os ossos do antebraço (rádio - ra e ulna -ul). O côndilo umeral apresenta duas projeções, a tróclea umeral e o capitulo umeral, circundados pelas fossas olecrana, coronóide e radial. Estas estruturas articulam-se, respectivamente, com a fóvea da cabeça do rádio, com a porção medial da circunferência articular (do rádio), com o tubérculo olecrano (da ulna), e com os processos coronóides medial e lateral (ulna).

A ulna é relativamente do mesmo comprimento que o rádio, porém mais larga e achatada dorso-ventralmente (Figs 28, 29). Na extremidade proximal, denominada olecrano (ol), diferenciam-se duas áreas de articulação, a lateral com a troclea umeral, e a medial com o tubérculo radial.

$\mathrm{O}$ rádio é mais estreito e cilíndrico do que a ulna. $\mathrm{Na}$ extremidade proximal diferenciam-se duas áreas de articulação, uma pouco profunda associada com o capitulo umeral, e outra mais profunda que se articula com o processo ancôneo (pan) da ulna (Fig. 29). A extremidade distal do rádio é tão expandida quanto a da ulna (Figs 28, 29).

O carpo é formado por nove pequenos ossos dispostos em duas séries, a proximal formada pelo ulnar (un), intermédio (it), e radial ( $r d$ ), e a distal composta pelo acessório (ace) e carpais I, II, III,IV e V (cI, cII, cIII, cIV e cV) (Figs 28, 29). 
Os cinco ossos metacarpais ( $\mathrm{mI}, \mathrm{mII}, \mathrm{mIII}, \mathrm{mIV}$ e $\mathrm{mV}$ ) não apresentam especializações, portanto, assemelham-se quanto à forma e dimensões (Figs 28, 29).

As falanges (fal) também são ossos pouco especializados e do mesmo modo que os metacarpais assemelham-se na forma e dimensões. O segundo, terceiro e quarto dígitos têm três falanges, e o primeiro e quinto dígitos apresentam duas falanges, deste modo, a fórmula falangeal de $T$. dorbignyi é 2-3-3-3-2 (Figs 28, 29). A falange terminal de cada um dos dígitos está envolta por tecido cornificado que se diferencia em uma garra (ga). (Figs 28, 29).

\section{Cintura Pélvica}

Os três ossos pareados que formam a cintura pélvica de $T$. dorbignyi mantêm o padrão observado nos Testudines, mas com relações próprias entre seus elementos formadores: os ílios (il) dorsais, e os ísquios (is) e os púbis (pu) ventrais (Figs 31, 32). A face costal do ílio (fci) é expandida crânio-caudalmente onde se diferenciam a área de articulação com as costelas sacrais, denominada articulação íliaca-costal (aic) (Figs 30, 32).

O corpo do ílio é robusto e pouco inclinado para a região caudal do corpo. $\mathrm{Na}$ face ventral do ílio (fvi) diferenciam-se duas margens, uma crânio-medial com o púbis, margem ilíaca-pubiana (mip), e uma medial com o ísquio, margem ilíacaisquiática (mii) (Fig. 32). O encontro das áreas de articulação do ílio, do ísquio e do púbis com o membro posterior delimitam uma fossa profunda o acetábulo (acet) (Figs 31, 32).

O ísquio é o menor dos ossos pélvicos e apresenta quatro margens a medial, a caudal, a cranial e a lateral. Na margem medial situa-se a sínfise isquiática (si), na lateral encontra-se a área de articulação com o ílio, denominada ísquiática-ilíaca, e no ponto médio da margem caudal diferencia-se um conspícuo processo metaisquiano (pmt) que se apoia sobre o plastrão (Figs 30,31). O ísquio encontra-se separado do púbis por uma grande abertura a janela pubico-isquiática (jpb) (Figs 30, 31).

O púbis, localizado crânio-ventralmente na cintura pélvica, tem dimensões maiores que o ísquio e sua porção cranial limita-se com a cartilagem epipubiana (cep) (Figs 30,31). Em sua margem medial situa-se a sínfise pubiana (sp). A margem caudal do púbis é acentuadamente côncava e delimita o limite cranial da janela pubico-isquiática. Em sua margem lateral situa-se a área de articulação com o ílio, margem pubico-ilíaca (mpi). Na porção média de sua margem cranial diferencia-se um grande processo lateral pubiano (plp) e do mesmo modo que como o processo metaisquiano, apoia-se sobre o plastrão ósseo (Fig. 30).

\section{Membros Posteriores}

O corpo do fêmur (fe) é cilíndrico e encurvado ao longo do seu maior eixo, semelhante ao observado para o úmero, definindo-se, deste modo, uma face medial (fme) convexa e uma face lateral (fl) côncava. $\mathrm{Na}$ extremidade proximal do fêmur diferencia-se sua cabeça (caf) onde localiza-se a área de articulação com o acetábulo (Figs 33, 34). Evidenciam-se duas projeções conspícuas nesta região, uma lateral, o trocanter maior (tmj), e uma medial, o trocanter menor (tmi). Estes tubérculos delimitam em sua face ventral uma fossa, a fossa inter-trocanter (fint) (Figs 33, 34). 

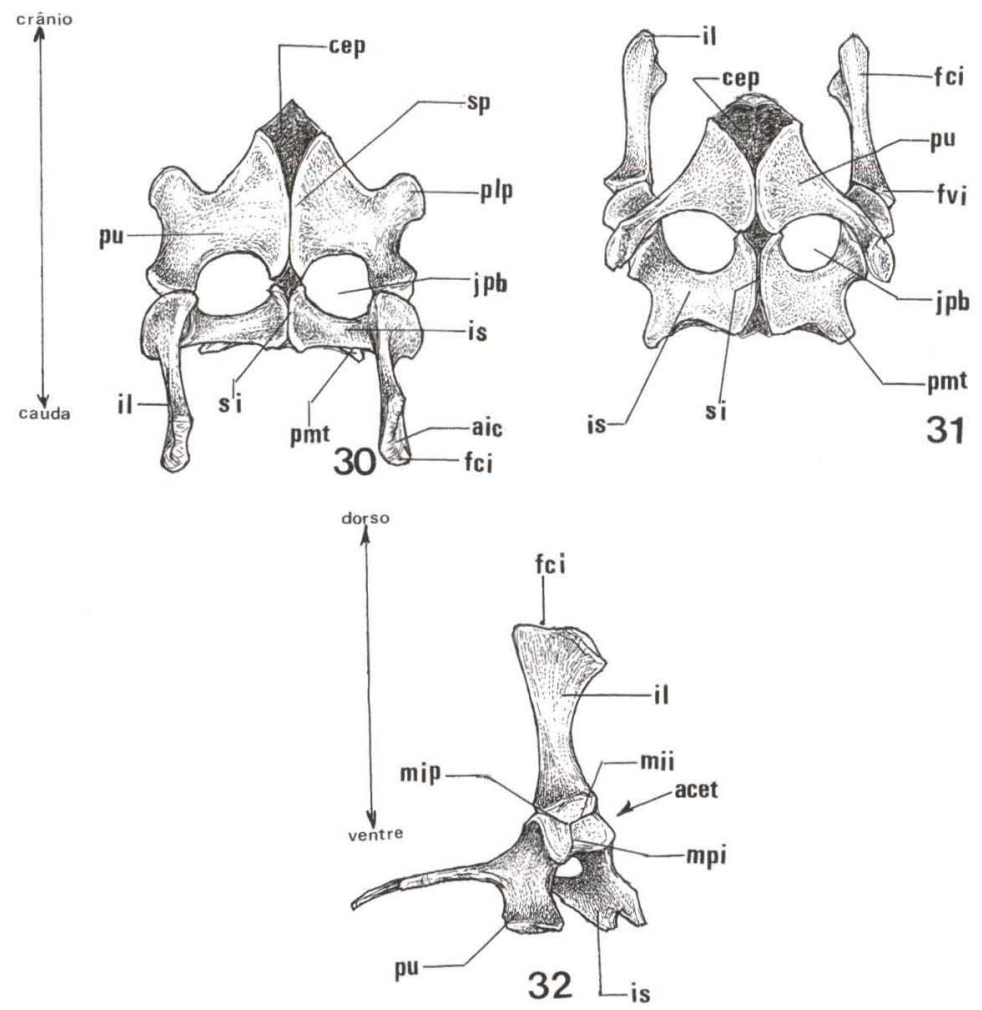

Figs 30-32. Trachemys dorbignyi, esquema da cintura pélvica. (30) Vista dorsal; (31) vista ventral, (32) vista lateral direita. (acet) Acetábulo, (aic) área de articulação iliaca-costal, (cep) cartilagem epipubiana, (fci) face costal do ílio, (fvi) face ventral do ílio, (jpb) janela pubisquiática, (il) ílio, (is) ísquio, (mii) margem íliaca-isquiática, (mip) margem iliaca-pubiana, (mpi) margem pubico-iliaca, (plp) processo lateral pubiano, (pmt) processo metaisquiano, (pu) púbis, (si) sínfise isquiática, (sp) sinfise pubiana.

A extremidade distal do fêmur é expandida e denominada tróclea femural (trf). Nesta região delimitam-se duas áreas de articulação, uma com a tíbia (ti), outra com a fíbula (fi). Diferenciam-se nestas áreas de articulação um côndilo ventro-caudal, o fibular (cf), e outro dorso-caudal, o tibial (cti) (Fig. 34).

A tíbia e a fibula têm praticamente o mesmo comprimento, no entanto a tíbia é mais larga o que lhe confere um aspecto robusto (Figs 33, 34). As extremidades proximal e distal destes dois ossos são expandidas latero-medialmente e alojam as articulações. A região proximal da tíbia é mais desenvolvida que a da fíbula, e na extremidade distal este padrão encontra-se invertido, isto é, a área de articulação da fíbula com os ossos tarsais é maior que existente entre a tíbia e os ossos tarsais. (Figs $33,34)$.

O tarso é formado por seis pequenos ossos dispostos em duas séries, a proximal composta pelo astrágalo (at) e o calcâneo (cal) e a distal pelos tarsais I, II, III e IV (tI, tII, tIII, tIV). O tarsal IV diferencia-se dos demais tarsais da série distal 
por ser tão largo quanto longo articulando-se com os metatarsos IV e V, e os tarsos tI, tII e tIII articulam-se, respectivamente, com os metatarsos mtI, mtII, e mtIII (Figs $33,34)$.

As falanges (fal) dos pés de $T$. dorbignyi na sua maioria assemelham-se quanto, a forma e dimensões, sendo as distais menores e envoltas por tecido cornificado diferenciado em garra (ga). O quinto dígito é o menor de todos pois, suas três falanges são, proporcionalmente, menores que as do segundo, terceiro e quarto dígitos. O primeiro dígito, por sua vez, é pouco menor que os dígitos segundo, terceiro e quarto, porque é formado apenas por duas falanges (Figs 33, 34). Deste modo, a fórmula falangeana do pé de $T$. dorbignyi. é 2-3-3-3-3 (Figs 33, 34).
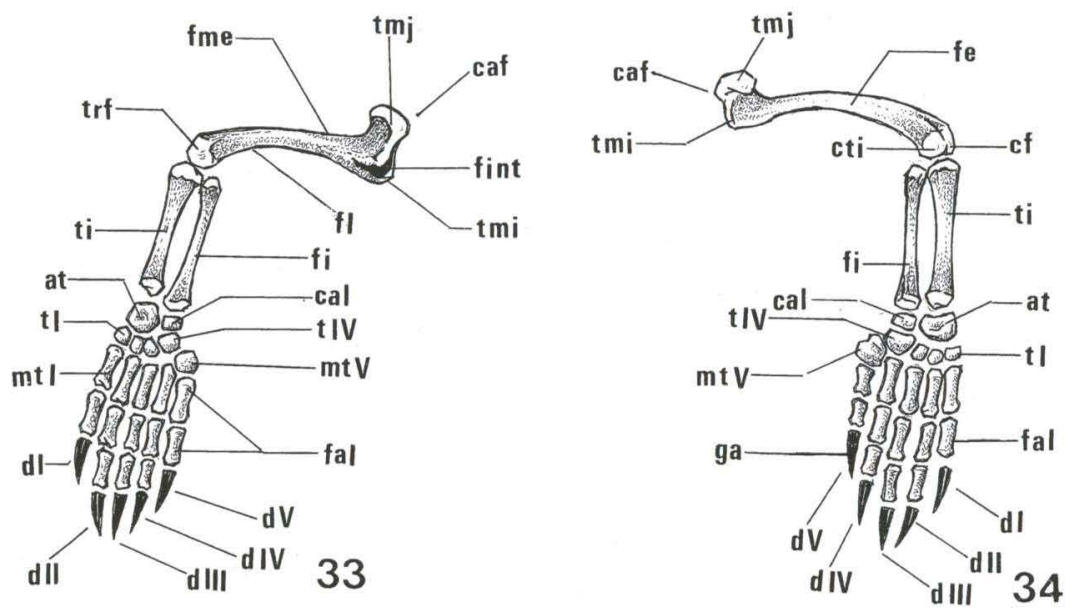

Figs 33-34. Trachemys dorbignyi, esquema do membro posterior esquerdo. (33) Vista lateral dorsal; (34) vista lateral ventral. (at) Astrágalo, (caf) cabeça do fêmur, (cal) calcâneo, (cf) côndilo fibular, (cti) côndilo tibial, (dl) primeiro dígito, (dlI) segundo dígito, (dIII) terceiro dígito, (dIV) quarto dígito, (dV) quinto dígito, (fal) falanges, (fe) fêmur, (fi) fibula, (fl) face lateral, (fme) face medial, (fal) falanges, (fi) fíbula, (fint) fossa inter-trocanter, (ga) garra, (mtl) primeiro metatarso, $(\mathrm{mtV})$ quinto metatarso, (tl) primeiro tarso, (tIV) quarto tarso, (ti) tíbia, (tmj) trocanter maior, (tmi) trocanter menor, (trf) tróclea femural.

\section{DISCUSSÃO}

Diante da diversidade dos Testudines há uma relativa carência de estudos anatômicos descritivos dos representantes deste táxon restringindo, de certo modo, as análises que envolvem o conhecimento de caracteres. Trabalhos osteológicos de revisão como o de ROMER (1956) ou STARCK (1979) mostram-se como balizadores importantes nos estudos osteológicos pois, definem padrões e variações das diferentes regiões esqueléticas dos Reptilia.

A análise do esqueleto de $T$. dorbignyi demostra padrões osteológicos semelhantes aos de Testudo europaea (= Emys orbicularis Linnaeus, 1758), descritos por BoJanus (1819-1821), ao de Testudo graeca Linnaeus, 1758 e Testudo ibera 
Pallas, 1814, descritos por THOMSON (1932), ao dos gêneros Chelydra Schweigger, 1814, Chrysemys e Pseudemys descritos por ASHLEY (1955), e o Clemmys marmorata Baird \& Girard, 1852, por NoBlE \& Noble (1940). Entretanto, algumas observações quanto a ossificação do esqueleto de $T$. dorbignyi sugerem a necessidade da continuidade e ampliação dos trabalhos de anatomia descritiva nos Testudines.

Quanto a ossificação da carapaça de $T$. dorbinyi observam-se áreas não ossificadas, ou seja, cartilaginosas, até uma idade relativamente avançada. Pode-se citar o representante BP2303 (fêmea com idade de 1233 dias), onde ainda havia várias partes cartilaginosas nas margens da carapaça, entre as placas costais e marginais mais caudais. Nos esquemas apresentados por BoJANUS (1819-1821) para Emys orbicularis e por THOMSON (1932) para Testudo graeca e Testudo ibera, partes não ossificadas da carapaça não foram apontadas. O mesmo ocorre nos atlas anatômicos de NoBle \& NoBle (1940) com Clemmys marmorata e ASHLEY (1955) com os gêneros Chelydra, Chrysemys e Pseudemys. Entretanto, nestes mesmos trabalhos há referência da ausência de ossificação de diferentes estruturas do esqueleto axial, também observadas em $T$. dorbignyi.

$\mathrm{O}$ fato dos autores supra citados não terem apontado a existência de áreas cartilaginosas na carapaça das espécies estudadas, pode ter sido porque o caráter não se mostrou relevante nas análises realizadas ou, talvez, porque o processo de ossificação foi completo. De qualquer modo, jovens e adultos de $T$. dorbignyi apresentam, ao longo do tempo, um gradiente crânio-caudal de ossificação da carapaça, fato não observado no plastrão, e nos espécimens recém-eclodios não observou-se ossificação em nenhuma das placas. O processo de ossificação diferenciado entre plastrão e carapaça, talvez, esteja relacionado com o padrão de crescimento desta espécie. Este fato sugere que processos de ossificação, semelhantes ou não ao de $T$. dorbignyi possam ocorrer em outros quelônios e o conhecimento de seu eventual significado merecem atenção e estudos.

A região lateral caudal do crânio de T.dorbignyi apresenta, o que definiu ROMER (1956), uma depressão posterior craniana [ou depressão temporal segundo BojANUS (1819-1821)]. O limite lateral de tal depressão em T. dorbignyi é definido pelo esquamosal e pós-orbital, sem a participação do quadrado jugal. Deste modo, o esquamosal perde contato com o parietal, semelhante ao padrão descrito para os gêneros Chelydra, Pseudemys, Emydoidea Gray, 1870 e Graptemys Agassiz, 1857, por ROMER (1956).

Em algumas espécies de quelônios, são apontadas diferenças na largura cefálica entre machos e fêmeas da mesma espécie. ERNST \& BARBOUR (1989) citam para várias espécies do gênero Graptemys Agassiz, 1857, uma maior largura cefálica nas fêmeas quando comparadas aos machos. MolinA (comunicação pessoal), ressalta que em $T$. dorbignyi as fêmeas adultas possuem a cabeça mais larga do que os machos. DARYMPLE (1977), estudando representantes do gênero Trionyx Geoffroy, 1809, descobre uma relação entre a forma das mandíbulas, mecanismo alimentar e dieta. Isso pode ser alterado com o crescimento do animal. No presente estudo, não encontramos diferenças nas estruturas morfológicas que formam o crânio e a mandíbula em jovens e adultos de machos e fêmeas. 
PRITCHARD (1984) aponta diferentes técnicas para a apreensão de peixes, realizadas por quelônios da família Chelidae, relacionando-as a algumas especializações morfológicas. Mediante essas informações, seria interessante comparar o mecanismo alimentar e dieta em diferentes idades para $T$. dorbignyi e relacioná-las à morfologia craniana.

A Ordem Testudines é dividida em duas subordens: Pleurodira e Cryptodira. A última apresenta a disposição das vértebras cervicais adaptadas para retração vertical sendo recolhidas formando uma curva sigmóide, conforme apontado por ERNST \& BARBOUR (1989). T. dorbignyi pertence a subordem Cryptodira, possuindo, portanto, retração vertical do pescoço onde as primeiras cinco vértebras cervicais alinham-se em uma paralela ao eixo crânio-caudal do corpo enquanto a $6^{\mathrm{a}}, 7^{\mathrm{a}}$ e $8^{\mathrm{a}}$ vértebras dispõem-se sobre uma reta oblíqua a este eixo. Esta disposição das vértebras cervicais delimita as duas regiões cervicais definidas por THOMSON (1932) para os criptodiros.

$\mathrm{O}$ esqueleto axial de $T$. dorbignyi segue o padrão estabelecido por ROMER (1956) para os Cryptodira. Quanto às vértebras cervicais $T$. dorbignyi apresenta o padrão de articulação dos centros vertebrais estabelecido por WILLIAMS (1950) para os Cryptodira. $\mathrm{O}$ atlas é característico, isto é, tem forma anelar, hipocentro reduzido, pós-zigapófises bem alargadas, e processos transversos diminutos. Observa-se em T. dorbignyi a presença de espaços relativamente grandes entre os arcos neurais [= spatium interarcuale BOJANUS (1819-1821)], devido ao comprimento relativamente maior dos corpos vertebrais cervicais, em relação ao dos arcos neurais correspondentes.

O aparelho hióideo de $T$. dorbignyi segue o padrão caracterizador dos Testudines descrito por ROMER (1956), isto é, trata-se de estrutura robusta, ossificada em sua maior parte, apresenta processo lingual (processo entoglossal). Situa-se no assoalho bucal e faríngeo, fixando-se aos diminutos processos occipitais e às incisuras jugulares através, respectivamente, dos epibranquiais I e II, de modo semelhante ao ilustrado por BOJANUS (1819-1821) para Emys orbicularis.

Segundo WALKER (1973), na grande maioria das espécies de quelônios a escápula e o processo acromial formam entre si um ângulo de $90^{\circ}$, sendo menor nas formas com carapaças acentuadamente achatadas dorso-ventralmente. A cintura peitoral de $T$. dorbignyi segue o padrão da maioria dos quelônios, isto é, escápula e processo acromial definem entre si um ângulo de $90^{\circ}$, assim como, a dimensão do coracóide e do processo acromial são semelhantes entre si. Observa-se a ausência de acentuada expansão da extremidade costal do coracóide presente nas formas com boa habilidade natatória (SZALAI 1932). Formas que apresentam boa natação têm, segundo WALKER (1973), o trocanter femural maior expressivamente mais desenvolvido que o menor. Este caráter não foi observado em $T$. dorbignyi onde a dimensão dos dois trocanteres femurais são semelhantes entre si, assim como, o observado em Pseudemys Gray, 1855 por ZUG (1971, apud WALKER 1973).

Observa-se que nos espécimes jovens e adultos de $T$. dorbignyi, a ausência de fusão entre os carpos (radial e acessório) e/ou dos tarsos (astrágalo e calcâneo), características observadas em Pseudemys (WALKER 1973) e Chrysemys (ROMER 
1956). Segundo WALKER (1973), a manutenção da individualidade do astrágalo e calcâneo, por exemplo, permitem ao animal uma leve rotação distal do membro e é um caráter presente em formas com boa habilidade natatória como os gêneros Caretta Rafinesque, 1814, e Eretmochelys, Fitzinger, 1843.

Quanto a forma e disposição dos metacarpos e metatarsos, e a fórmula falangeal da mão e do pé de $T$. dorbignyi seguem o padrão descrito para a maioria dos quelônios (ROMER 1956; WALKER 1973). Há uma forte semelhança destes caracteres com os observados por WALKER (1973) em Pseudemys scripta elegans, no entanto, a ausência de fusão dos carpos e tarsos somada a presença de garras associadas a todas as falanges distais da mão e pé de $T$. dorbignyi sugerem estudos relacionados aos processos de locomoção desta espécie.

A nomenclatura adotada neste trabalho foi fundamentada na literatura especializada e nas normas publicadas na Nômina Anatômica, Histológica e Embriológica Veterinária (1994). A nominata publicada nas Nôminas Anatômicas fundamenta-se na homologia das estruturas e, por não existir uma Nômina específica para os Reptilia, alerta-se para o cuidado na utilização dos termos, pois, devem se restringir a estruturas homólogas àquelas publicadas para aves, mamíferos domésticos e seres humanos.

Dentre os trabalhos de anatomia descritiva de quelônios há de se ressaltar a importância do estudo de BoJANUS (1819-1821). Como bem observou Romer (1970), na introdução da reedição do trabalho de BojANUS (1819-1821), apesar da nominata proposta pelo autor mostrar-se antiquada, as detalhadas ilustrações são uma fonte inestimável de informações que fundamentam e orientam os trabalhos mais recentes.

A adoção das normas publicadas na Nômina norteou a definição de termos o que auxiliou sobre maneira este trabalho. É o caso, por exemplo dos nomes vinculados às articulações, como margem escapular-coracóidea ou face de articulação escapular-umeral, ou outros relacionados a localização de regiões ou partes de uma estrutura, como por exemplo, face costal do ílio, ou extremidade distal do úmero, ou crista medial dorsal do supra-angular. Já, nomes como, côndilo umeral, tróclea umeral, capitulo umeral, fossa olecrana, coronóide e radial foram adotados da nominata estabelecida para os mamíferos, pois, os ossos em questão são homólogos nos Reptilia e Mammalia.

A maioria dos termos consagrados na literatura especializada mostram-se adequados sob o ponto de vista das normas. É o caso de forame alar, hipocentro, hipoapófise, ou janela medial do corpo hióideo (definidos por THOMSON 1932) em substituição, respectivamente, a forame medular, massa lateral, espinho vertebral ventral e fóvea fenestrada (definidos por BoJANUS 1819-1821). Já o termo janela tireóidea utilizado por WALKER (1973) em substituição a forame obturador (BOJANUS 1819-1821; NOBLE \& NOBLE 1940), ou forame pubisquiático (THOMSON 1932) deveria ser reavaliado sob a luz das normas. Entre as orientações estabelecidas os termos anatômicos devem ser fáceis de memorizar e sobre tudo, apresentar valor descritivo e informativo, diante disso o nome pubico-isquiática mostra-se mais adequado que tireóidea para esta janela da cintura pélvica. 
Mediante as questões colocadas sugere-se a utilização das normas publicadas nas Nôminas, corroborando com a proposta de GAFFNEY (1972) que ressalta a importância de padronizar os termos anatômicos, até para simplificar e agilizar os trabalhos descritivos em quelônios, e a elaboração de Nômina específica para Reptilia, cuja aplicação mostra-se de incontestável utilidade na área anatômica.

AGRADECIMENTOS. Em especial, a Fundação Parque Zoológico de São Paulo, em nome do Diretor, Dr. Adayr Saliba, ao chefe do setor de répteis, Mário Borges da Rocha e ao biólogo Dr. Flávio de Barros Molina, pelo empréstimo do material e apoio recebido. A Isnard Souza Rubim, taxidermista do Museu de Zoologia da USP, pelo preparo do esqueleto de alguns exemplares. A Giuseppe Puorto do Instituto Butantã, pela foto $1(A)$ e a Glória Jaffet da Fundação Parque Zoológico de São Paulo, pela foto 1(B). À Fundação Universidade do Tocantins, Campus Universitário de Araguaina, em nome do atual Diretor Geraldo da Silva Gomes e da Diretora Wadya Carvalho de Oliveira, pelo apoio recebido. Ao Sr. Ricardo Cavani Rosas pelos trabalhos de ilustração e arte final. Ao pessoal técnico da Seção de Peixes do Museu de Zoologia, USP no auxílio da preparação de alguns dos esqueletos estudados.

\section{REFERÊNCIAS BIBLIOGRÁFICAS}

Ashley, L.M. 1955. Laboratory Anatomy of the Turtle. Iowa, WM.C. Browm Co., 48p.

Bojanus, L.H. 1819-1821. Anatome Testudinis Europaeae. Vilnae (reeditada pela Society for The Study of Amphibians and Reptiles, 1970).

CAGLE, F.R. 1946. The Growth of Slider Turtle, Pseudemys scripta elegans. Amer. Mid. Natur. 36: 685-729.

DARYMPLE, G.H. 1977. Intraspecific Variation in the Cranial Feeding Mechanism of Turtles of the Genus Trionyx (Reptilia, Testudines, Trionychidae). Jour. Herpetol. 11 (3): 255-285.

ERnst, C.H. \& R.W. BARBour. 1989. Turtles of the World. Washington, Smithsonian Inst. Press, 313p. Gaffney, E.S. 1972. An Illustrated Glossary of Turtle Skull Nomenclature. Amer. Mus. Novit. 2486: $1-33$.

Gomes, N. 1994. Linhas Gerais de Pesquisa em Herpetologia: Morfologia de Répteis, p. 128-129. In: L.B. Nascimento (Ed). Herpetologia no Brasil. Belo Horizonte, PUC-MG, Fundação Ezequiel Dias.

Gomes, N.; G. Puorto; M.A. Buononato \& M.F.M. RiBeiro. 1989. Atlas Anatômico de Boa constrictor Linnaeus, 1758 (Serpentes; Boidae). Monogr. Inst. Butantan 1989 (2): 1-59.

Medem, F. 1976. Recomendaciones Respecto a Contar el Escamado y Tomar Dimensiones de Nidos, Huevos y Ejemplares de los Crocodylia y Testudines. Lozania 20: 1-17.

Noble, G.A. \& E.R. NoBle. 1940. A Brief Anatomy of the Turtle. California, Standford University Press, $46 \mathrm{p}$.

PrITCHARD, P.C.H. 1979. Encyclopedia of Turtles. Neptune City, N.J., TFH Publ., 895p.

- 1984. Piscivory in Turtles, and Evolution of the Long- necked Chelidae. In: M.W.J. FERGUNSON (Ed.). Symp. Zool. Soc. London 1984 (52): 87-110.

Pritchard, P.C.H. \& P. TrebBau. 1984. Turtles of Venezuela. Caracas, Soc. Study of Amphibians and Reptiles, $403 \mathrm{p}$.

Rhodin, A.G.J. \& R.A. MitTERmeier. 1976. Chelodina parkeri, a new species of chelid turtle from New Guinea, with a discussion of Chelodina siebenrocki Werner, 1901. Bull. Mus. Comp. Zool., Harvard, 147 (11): 465-488.

ROMER, A.S. 1956. Osteology of the reptiles. Chicago, Univ. Chicago Press, 772p.

Seidel, M.E. \& H.M. SMith. 1986. Chrysemys, Pseudemys, Trachemys (Testudines: Emydidae): Did Agassiz Have It Right? Herpetol. 42 (2): 242-248. 
StARCK, D. 1979. Vergleichende Anatomie der Wirbeltiere. 2 Das Skeletsystem Allgemeines, Skeletsubstanzen, Skelet der Wirbeltiere einschlieBlich Lokomotionstypen. Berlin, Springer-Verlag, vol. 2, 776p.

SzALAI, T. (1932-33). II. Biomechanische Untersuchungen am Schultergürtel der Testudinaten. Ann. Naturhist. Mus. Wien 46: 157-163.

TAYLOR, W.R.; G.C. VAN DYKE. 1985. Revised Procedures for staining and clearing small fishes and others vertebrates for bones and cartilage study. Cybium 9 (2): 107-119.

The World Association of Veterinary Anatomists. 1994. Nomina Anatômica Veterinária 4.ed.

Nomina Histológica 2.ed. Nomina Embriológica Veterinária 1.ed. New York, Department of Veterinary Anatomy, 200p.

Thomson, J.S. 1932. The Anatomy of the Tortoise. Sci. Proc. Royal Dublin Soc. 20 (28): 359-461.

VANZolInI, P.E. 1995. A New Species of Turtle, Genus Trachemys, from the State of Maranhão, Brazil (Testudines, Emydidae). Rev. Brasil. Biol. 55 (1): 111-125.

WALKER, J.R. \& F. WARREN. 1973. The Locomotor Apparatus of Testudines. In: C. GANS (Ed.). Biology of Reptilia. London, Academic Press, 100p.

Williams, E.E. 1950. Variation and seletion in the cervical central articulations of living tutles. Bull.

Amer. Mus. Nat. Hist. 94: 505-62.

Recebido em 09.IX.1999; aceito em 13.XII.2000. 